\title{
Does Technology Matter When Selecting a Target Firm in an M\&A? Some Evidence on a European M\&A Sample
}

\author{
Barbara Fidanza ${ }^{1}$ \\ ${ }^{1}$ Department of Law, University of Macerata, Macerata, Italy \\ Correspondence: Barbara Fidanza, Department of Law, University of Macerata, Piaggia dell'Università 2, 62100 \\ Macerata, Italy.
}

Received: March 12, 2019

Accepted: April 22, $2019 \quad$ Online Published: April 24, 2019

doi:10.5539/ibr.v12n5p111

URL: https://doi.org/10.5539/ibr.v12n5p111

\begin{abstract}
Using a sample of European M\&As from 2009 to 2017, this work assesses whether there is a linkage between a firm's innovation orientation and its participation in an M\&A. This main aim has been divided into three aims: defining the target firms' characteristics in M\&A deals with a special focus on innovation orientation, performance, financial structure and size; understanding what kind of firm is generally acquired from institutional investors; describing the effects of M\&A deals on the targets. With reference to the analysis method, aims were pursued through logistic regressions on the cross-sectional sample and by comparing pre-deal and post-deal average balance values.

The result is twofold. First, a high probability of being targeted is associated with high portfolio patents and low research and development costs of a firm, but only in cases of technological overlap; otherwise the R\&D intensity, performance and size of firms are relevant. Second, when analysing the effects of M\&As, comparing the same variables in post vs. pre deal period, they are only significant for patent and R\&D costs. These results confirm that the M\&A transactions produce useful synergy in terms of innovation capability.
\end{abstract}

Keywords: innovation, M\&A, R\&D expenses, patent portfolio, synergies, technological overlap

\section{Introduction}

The globalization of markets has made it increasingly important for companies to plan effective growth strategies as far as financial and non-financial performance is concerned.

Growth can be achieved in two ways: with a firm's internal development or with external acquisition of firm capacity. Frequently, growth is internal; it is characterized by simplicity, autonomy and flexibility. On the other hand, a growth process based on merger and acquisition (M\&A) deals enables a company to be more reactive to the changing market conditions, also limiting the investment risk level in research and development.

The success and exponential growth of the M\&A market have been known since 1980, but the main M\&A deals in the USA area took place at the end of 1800. Due to long temporal lags from when the first phenomena were manifested and then recognized, a proliferation of empirical and theoretical studies analysing many aspects of M\&As can be observed.

There are two streams of literature. The first studies focus attention on the drivers used by management when selecting target firms, the second studies analyse the performance of participant firms in M\&As.

One of the principal factors recognizable as determinants when selecting target firms is, in the literature, the target firm's technological development, approximated from skills and knowledge patent intensity or from the intensity of $R \& D$ investment (more $R \& D$ investment is interpreted as being stronger innovation orientation). Empirical results demonstrate that the degree of a target firm's technology innovation determines M\&A success; in US markets, these results have been used to recognize a group of M\&A activities named Technology M\&A, whereas in Europe these aspects have been examined less thoroughly.

This paper is motivated by this lack of diffusion; the main aim has been to test the importance of the technology factor in selecting target firms and it has been divided into the three aims listed below.

- Aim 1 - defining the target firms' characteristics in M\&A deals with a special focus on innovation orientation, performance, financial structure and size. 
- Aim 2 - understanding what kind of firm is generally acquired from institutional investors; these investors certainly do not have technological overlap with the target (the target firms in the sample are non-financial, see Section 3-4).

- Aim 3 - describing the effects of M\&A deals on the targets.

The paper proceeds as follows. Section 2 contains a review of the international empirical literature, the aim is to recognize the most important determinants of M\&A deals and offer some reflections on a linkage between M\&A deals and technological innovation. Sections 3 and 4 contain, respectively, sample and analysis models used in present empirical testing; Section 5 includes the major results and Section 6 offers a conclusion.

\section{International Empirical Evidence}

The debate on a firm's motivation to be a part of M\&A deals is complex. In the main hypothesis there is the will to: increase market share; diversify risk by entering new markets (new country, new customers) or vertical integration; improve efficiency (with scale economies and synergies in production and/or marketing and/or R\&D investment); increase ownership control; build an empire; acquire assets (Andrade, Mitchell \& Stafford, 2001; Capron, Dussauge \& Mitchell, 1998; Chakrabarti, Hauschildt \& Süverkrüp, 1994; Haspeslagh \& Jemison, 1991; Jensen \& Ruback, 1983; Seth, 1990; Dezi, Battisti, Ferraris \& Papa, 2018).

The motivations based on the counterpart knowledge concern technological aspects, important elements of competitive advantage and learning abilities (Mowery, Oxley \& Silverman, 1996; Teece \& Pisano, 1994). Obtaining technology when acquiring another firm may be convenient with regard to the in-house development of technology because high R\&D investment is required. Innovation incentives, in term of productivity, are different in large and small firms: generally, large firms acquire small innovative firms to take in new technology.

For example, many deals are motivated by technology acquisition made in pharmaceutical and biotechnological sectors: the big firms acquire the small firms with the aim of reducing R\&D costs due to the effect of scale economy and/or the development of new generation of drugs (Danzon, Epstein \& Nicholson, 2007; Higgins \& Rodriguez, 2006; Munos, 2009; Schweizer, 2005).

In the telecommunications sector, Cisco is often described as a firm that acquires technology, skills and competence from other firms (Mayer \& Kenney, 2004; Ranft \& Lord, 2000, 2002).

To summarize, the technological reasons for acquiring another firm may be justified in different ways.

- Reducing costs: possibility to adopt scale economy through the distribution of fixed costs on more outputs or more areas (Cassiman \& Ueda, 2006). Furthermore, an M\&A deal may be used to avoid project duplication (Comanor \& Scherer, 2012).

- Creating synergy, combining skills to generate new opportunities: for example, a firm may acquire another firm with complementary technological know-how. The use of this know-how combined with its own skills guarantees an increase in productivity and new product development (Barney 1988; Karim \& Mitchell, 2000; Hussinger, 2010).

- Exploring and adapting to the changing environment: external new technology acquisition allows the firm to adapt to changing markets more rapidly than internal development (Dierickx \& Cool, 1989; Teece \& Pisano 1994) and overcome static skill staticity (Levitt \& March, 1988; Vermeulen \& Barkema, 2001).

- Reducing uncertainty and risk: the acquisition of distant technology allows for diversification and reduces exposure to risks in the starting sector. The M\&A deals may help the firm to implement large and costly R\&D projects; finally, the acquisition of tested technology reduces uncertainty.

- Implementing strategies: this includes the acquisition of firms with replacement technologies to allow present and future changes in competition, for example, the acquisition of patent portfolios to resolve a patent dispute or create a patent network and block third-party competition (Gans \& Stern, 2000; Grimpe \& Hussinger, 2008, 2013; Lerner, Tirole \& Strojwas, 2003).

- Accessing scarce resources: the acquirer may be interested in a firm that has skills in its own technology, for example, qualified engineers (Ranft \& Lord, 2000).

The companies' reasons for taking part in M\&A transactions play a crucial role in understanding how the characteristics of the involved companies, the criteria according to which the acquirers identify the targets and the main post-deals effects, depend on technological aspects. For example, if the main aim is technological 
diversification, a company will probably look for companies with greater technological distance; if the goal is to generate scale economies and avoiding duplication, the acquired company should be fairly close to the purchaser from a technological point of view.

On the subject of interaction between M\&As and technological aspects, this research area has had significant development (Ahujan \& Katila, 2001; ;spepiBower 2001; Cantwell \& Santangelo, 2006; Chakrabarti et al., 1994; Cohen \& Levinthal,s[sp:1 1989; Granstrand, Bohlin, Oskarsson, \& Sjöberg, 1992; Grimpe \& Hussinger, 2008, 2013; Keil, Maula, Schildt \& Zahra, 2008; Schweizer, 2005) and below I will attempt to highlight the main findings on the topic by dividing them up according to the determinant of interdependence.

\subsection{Degree of Innovation}

The interactions between the degree of innovation, growth and productivity have interested scholars for a long time. Innovation has always been considered the key driver of value creation in a company.

Most studies have examined how, both from a financial and a governance point of view, it is preferable to favour innovation with internal resources. Conversely, if M\&As are activated, unfavourable circles could be triggered: establishing a purchase value requires disclosure of information that would reduce the innovation gap with competitors and a potential buyer would have a lower incentive to pay once such information has been disseminated. Other authors believe it is essential to activate M\&A deals to innovate (Holmstrom \& Roberts, 1998). Hart \& Holmstrom (2010) show that when the productions of two companies present externalities, for example, when they need to coordinate their technologies, a merger facilitates coordination that could not otherwise be achieved.

Other studies (Bena \& Li, 2014; Haucap \& Stiebale, 2016; Frey \& Hussinger, 2006; Makri, Hitt \& Lane, 2010) show that, in the pre-acquisition stage, firms with a significant patent portfolio and reduced exposure to research and development tend to become acquirers in a acquisition and, conversely, companies with a high investment in research and development and a weak weight of the patent component present are more likely to be targets. Bena $\& \mathrm{Li}$ (2014) generally argue that participants in a merger carry out $\mathrm{R} \& \mathrm{D}$ activities prior to acquisition.

These debates indicate that the greater the level of firm innovation, the more likely it will participate in M\&As.

\subsection{Technological Overlap}

For different aspects, technological proximity seems to be important in explaining which elements buyers consider in order to choose future target firms.

First, technological overlap can help overcome information asymmetry in transactions, an undisputed advantage when the parties are aware that intellectual property and technological know-how are more difficult to evaluate than material activities; in these contexts, therefore, price determination between the parties is facilitated (Kaplan 2000, Higgins and Rodriguez 2006). Moreover, technological overlap can lead to scale economies in innovation, for example, research and development costs can be reduced (Henderson \& Cockburn 1996; Bena \& Li 2014). Last but not least, it must be borne in mind that the technologies of the counterparty can fill the gaps in the patent portfolio, ensuring greater innovation strength and better competitive positioning (Cassiman \& Colombo, 2006; Cassiman \& Veugelers, 2006).

However, too much technological proximity risks limiting learning opportunities, increasing new knowledge and acquiring future skills (Ahuja \& Katila, 2001; Nooteboom, Van Haverbeke, Duysters, Gilsing \& Van den Oord, 2007; Sapienza, Parhankangas \& Autio, 2004).

From a theoretical perspective, therefore, technological proximity can be both advantageous and harmful, but it is believed that buyers are more likely to acquire target companies with which they have overlaps of innovation activities or similar levels of technological expertise.

\subsection{Overlap in the Outlet Market}

Using a text analysis of company product descriptions, Hoberg \& Phillips (2010) show that, on equal terms, companies with broad similarities in the outlet market are more likely to be merged. At the same time, their results suggest that the most direct competitors (companies with very strong similarities) compete for the same growth opportunities and market share; this competition reduces the likelihood of a merger. The research and development efforts of these rival companies can lead to the introduction of new products or services, further intensifying competition in the product market (Bloom, Schankerman \& Van Reenen, 2013).

For these aspects, very similar pairs of companies, which also overlap in product markets, reduce the positive effect of technological overlap on the probability of implementing a merger. 


\subsection{Innovation Degree and Post-Deal Effect}

To determine if the technological aspect is a key factor in an M\&A, it is also interesting to understand the post-deal effect in terms of innovation.

Maksimovic, Phillips \& Prabhala (2011) believe that the productivity of the acquired assets increases in acquisitions operating in the same sector as the purchaser. Fan \& Goyal (2006) believe that the mergers put in place to facilitate vertical integration produce greater value than those implemented with the aim of diversifying activities. Ahuja \& Katila (2001) show that the link between technological correlation and productivity is very strong in the chemical sector.

These results show that the positive effects of a merger are greater the higher the level of technological innovation and technological overlap.

\section{The Sample}

The sample used in the various analysis steps is a cross-sectional sample composed of:

- 257 non-financial target firms in M\&As;

- 115 institutional investor acquirers in M\&As;

- 444 non-financial firms, not included in M\&As and operating in the same sector as the target firms and of a similar size.

For the definition of the sample we proceeded as outlined below.

M\&A transactions were identified between 2009 and 2017 in the European market using the Merger Market database. In the nine year period, we identified thousands of M\&A transactions in which at least one of the counterparties had its registered office in Europe. From this first selection, they were then subsequently reduced: transactions in which the target firms' activity was a financial one were excluded; operations that more than one target or acquirer participated in were not considered; transactions in which the acquisition of share was not direct (from acquirer to target), but through other companies, were also excluded. The number of deals was then further reduced, maintaining only those for which data was available, both for the target and the acquirer, in the year of the deal and in the following and previous year. These filters resulted in 257 deals with non-financial target firms; in 115 deals the acquirer is an institutional investor.

In the sample there are also 444 comparable firms, not subject to M\&As, defined using the following criteria:

- for each target, a group of companies not included in the M\&A and operating in the same sector as the target firm was identified;

- this group of companies was reduced, excluding companies that differed from the target firm by more than $50 \%$ according to three dimensional variables (number of employees, sales and total assets).

The following table shows the distribution of the target firms in macro-sectors of activity; manufacturing is the most represented, followed by the wholesale and retail trade and the other macro-areas have low numbers. Within the manufacturing sector, M\&A deals primary concerned companies belonging to sectors that can be considered characterized by a high level of innovation (pharmaceutical, chemical, textile, food, oil products production, production of electronic/electrical/machinery). 
Table 1. Target firms distribution for activity macro-sectors

\begin{tabular}{|c|c|c|}
\hline Description & & Number \\
\hline Agricultural crops and production of animal products, hunting and related services & & 2 \\
\hline Manufacturing activities & & 199 \\
\hline Pharmaceutical & 49 & \\
\hline Chemical & 40 & \\
\hline Textile & 31 & \\
\hline Food & 26 & \\
\hline Oil products production & 23 & \\
\hline Production of electronic/electrical/machinery & 20 & \\
\hline Other & 10 & \\
\hline Supply of electricity and gas & & 2 \\
\hline Buildings & & 6 \\
\hline Wholesale and retail trade & & 38 \\
\hline Information and communication services & & 2 \\
\hline Real estate activities & & 4 \\
\hline Rental and travel agencies & & 4 \\
\hline
\end{tabular}

Table 2. Target firms distribution for size

\begin{tabular}{|c|c|c|c|c|c|}
\hline \multicolumn{3}{|c|}{ Number of employees } & \multicolumn{3}{|c|}{ Sales (millions of $€$ ) } \\
\hline over 250 & 28 & $11 \%$ & over 50 & 41 & $16 \%$ \\
\hline $50-250$ & 113 & $44 \%$ & $10-50$ & 131 & $51 \%$ \\
\hline $10-50$ & 90 & $35 \%$ & $2-10$ & 59 & $23 \%$ \\
\hline under 10 & 26 & $10 \%$ & under 2 & 26 & $10 \%$ \\
\hline Total & 257 & $100 \%$ & Total & 257 & $100 \%$ \\
\hline
\end{tabular}

The target firms in M\&As are mainly SMEs (Table 2): $89 \%$ have fewer than 250 employees and $84 \%$ fewer than 50 million sales, this information is consistent with the findings of the empirical literature on the topic. Bena \& Li (2014) highlighted in the US market a greater incidence of acquisitions made from large bidder versus micro or small target firms, highly exposed to R\&D investments.

\section{Method and Variables Used}

With reference to the analysis method, aims 1 and 2 (Section 1) were pursued through a logistic regression on the cross-sectional sample described in the previous section whereas aim 3 was obtained by comparing pre-deal and post-deal average balance values. Details of the models used can be found below as well as the variables included in them.

Aim 1 -defining the target firms' characteristics in $M \& A$ deals with particular attention to innovation orientation, performance, financial structure and size.

$$
\text { DummyTarget }_{i, t}=\alpha+\beta_{1} C I_{i, t-1}+\beta_{2} C P_{i, t-1}+\beta_{3} C F_{i, t-1}+\beta_{4} C S_{i, t-1}+e_{i, t-1}
$$

where:

DummyTarget $_{i, t}=$ binary variables that assume value 1 if the firm $i$ at time $t$ is a target of M\&A deal, 0 otherwise;

$C I_{i, t-1}=$ variables describing at time $t-1$ the innovation degree of target firm $i$;

$C P_{i, t-1}=$ variables describing at time $t-1$ the performance of target firm $i$;

$C F_{i, t-1}=$ variables describing at time $t-1$ the financial structure of target firm $i$;

$C S_{i, t-1}=$ variables describing at time $t-1$ the size of target firm $i$.

The model is applied to a sample of 701 firms (257 non-financial firms of M\&A deals and 444 non-financial firms not included in M\&As).

Aim 2 - understanding what kind of firm is generally acquired from institutional investors; these investors certainly do not have technological overlap with the target.

$$
\text { DummyIstitutional }_{j, d, t}=\alpha+\beta_{1} C I_{i, d, t-1}+\beta_{2} C P_{i, d, t-1}+\beta_{3} C F_{i, d, t-1}+\beta_{4} C S_{i, d, t-1}+e_{i, d, t-1}
$$
where:

DummyIstitutional $_{j, d, t}=$ binary variables that assume value 1 if the acquirer firm $j$ in deal $d$ at time $t$ is a institutional investor, 0 otherwise; 
$C I_{i, d, t-1}=$ variables describing at time $t-1$ the innovation degree of target firm $i$ of deal $d$ (made in time $t$ );

$C P_{i, d, t-1}=$ variables describing at time $t-1$ the performance of target firm $i$ of deal $d$ (made in time $t$ );

$C F_{i, d, t-1}=$ variables describing at time $t-1$ the financial structure of target firm $i$ of deal $d$ (made in time $t$ );

$C S_{i, d, t-1}=$ variables describing at time $t-1$ the size of target firm $i$ of deal $d$ (made in time $t$ ).

The model is applied to a sample of $257 \mathrm{M} \& \mathrm{~A}$ deals.

Table 3. Independent variables

\begin{tabular}{|c|c|c|c|c|}
\hline & & Variable & Abbreviation & Definition \\
\hline \multirow{4}{*}{ 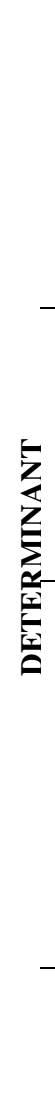 } & 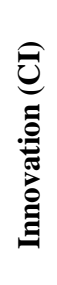 & $\begin{array}{c}\text { Intensity of patent } \\
\text { investments } \\
\text { Intensity of investments in } \\
\text { R\&D }\end{array}$ & $\begin{array}{l}\text { PAT } \\
\text { RD }\end{array}$ & $\begin{array}{l}\frac{\text { patents value }}{\text { total asset }} \\
\frac{\text { investment in } R \& D}{\text { total asset }}\end{array}$ \\
\hline & 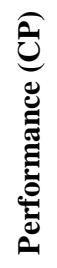 & $\begin{array}{c}\text { Return on asset } \\
\text { Capability to produce cash } \\
\text { flows }\end{array}$ & ROA & $\begin{array}{c}\frac{E B I T}{\text { total asset }} \\
\frac{\text { profit }- \text { investment }+ \text { depreciation }}{\text { total asset }}\end{array}$ \\
\hline & 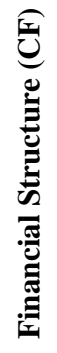 & Leverage & LE & $\frac{\text { short term debt }+ \text { long term debt }}{\text { total asset }}$ \\
\hline & 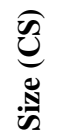 & $\begin{array}{c}\text { Total assets } \\
\text { Sales }\end{array}$ & $\begin{array}{l}\text { TA } \\
\text { SAL }\end{array}$ & $\begin{array}{c}\ln (\text { total asset }) \\
\ln (\text { sales })\end{array}$ \\
\hline
\end{tabular}

\section{Aim 3-describing the effects of $M \& A$ deals on targets.}

For every variable included in the two previous models and observed for target firms of deal $d$ at time $t$, the cross-sectional average value calculated at time $t-1$ was compared with that calculated at time $t+1 .{ }^{1}$

As regards the variables included in the model, we discussed in Section 3 the relevance of innovation orientation as a driver of M\&A deals. Alongside this driver, different studies have also referred to factors not directly attributable to the technological level, but which can be useful in defining the characteristics of the acquisition transactions concluded. In this overall framework, we chose to include several independent variables in the model; Table 3 divides them according to the determinant of which they are proxies, giving a description of the calculation methods and the abbreviations used in the display of the results.

\section{Results}

With reference to aims 1 and 2, 15 regressions were conducted, differentiated by number and type of variables included. They are described below.

- 7 single regressions between the dependent variable and each of the variables inserted in the model (regression 1, 2, 3, 4, 5, 6, 7).

${ }^{1}$ The statistical significance of the difference between the averages values was tested by the Student's T, in the comparison of averages I used the Student's T test for paired data. 
- 6 multiple regressions between dependent variable and combinations of independent variables: two variables for the technological determinant (regression 8) and combinations between the two technological variables with the remaining variables taken individually (regression 9, 10, 11, 12, 13). In this way, we wanted to verify whether the traditional drivers have a greater/less explanatory power when combined with the technological determinant.

- A multiple regression between dependent variable and all independent variables (regression 14).

- A multiple regression between dependent variable and 5 independent variables, the size determinant has been omitted to prevent the results being affected by multicollinearity between the variables (regression 15$)^{2}$

Tables 4 and 5 contain, respectively, the results of the 15 regressions with reference to aims 1 and 2: the coefficients are given for each regression (the number of regression to which it refers is that of the column), their statistical significance calculated using the Student's $\mathrm{T}$ test and the $\mathrm{R}^{2}$.

Aim 1 -defining the target firms' characteristics in $M \& A$ deals, with a special focus on innovation orientation, performance, financial structure and size

An analysis of single regressions (1-7) shows that none of the single variables seem to be a determinant of being a target in an M\&A, none of the regression coefficients are statistically different from zero and the values of $\mathrm{R}^{2}$ are always very close to zero with a capacity, therefore, nothing of the dependent variable that can explain the variability of the independent one.

The results of multiple regressions, on the other hand, lead to some statistically significant relationships as described below.

- In all the multiple regressions, with reference to the innovation orientation, the coefficient relative to the PAT variable is positive whereas the one relative to RD variable is negative and always statistically significant.

- The other variables are statically significant only in regression 15 in which the innovation variable is combined with performance and financial structure, among other things, this is the only model in which the $\mathrm{R}^{2}$ has an acceptable value, $41 \%$ of the variability of the dummy is explained by the three determinants.

- In regression 15 the coefficients found for ROA and LE are positive whereas the coefficient for CF is negative.

- Even if the dimension coefficient is not significant, its negativity indicates that the targets are generally smaller companies.

From this scenario, the target firms of M\&As, compared with similar companies not subject to transactions show, in the period before the operation: a higher value of patent investment, less R\&D expenditure, better accounting but not financial performance and a higher level of debt.

The results here highlighted agree with the empirical literature according to which the targets generally present low R\&D intensity and high patent portfolio compared to the non-acquired companies, but at the same time, a weak financial situation. In general, this trend is explained by the need for companies that have been strong innovators in the past, but are suffering from a deterioration in their situation in terms of innovation and financial performance, to find new capitals that give life to their business (Bloningen \& Taylor, 2000; Desyllas \& Hughes, 2010).

The result related to patent costs is contrary to what Bena \& Li (2014) and Gantumur \& Stephan (2010) affirmed: these studies identify the tendency of US companies with a larger patent portfolio to became acquirers and not targets in acquisition transactions.

Aim 2 - understanding what kind of firm is generally acquired from institutional investors, these investors certainly do not have technological overlap with the target

With reference to the aim, the coefficients contained in Table 5 show that:

${ }^{2}$ The Total Asset used as proxy of the dimension was also used to standardize the remaining variables, the risk of a high correlation between two or more explanatory variables was, therefore, high; however, the tests exclude the possibility of bias. 
- coefficients relating to innovation variables are always positive, but only the coefficient relative to the intensity of R\&D is statistically significant;

- performance and size variables indicate, respectively, a direct and inverse relationship with the dependent variable, the coefficients are only significant when coupled with the innovation degree and the models show an acceptable $\mathrm{R}^{2}$;

- leverage does not seem useful in explaining the choice of institutional investors.

Reading these results, the target firms acquired by investors that do not have the conditions for a technological overlap with them show a greater intensity of $\mathrm{R} \& \mathrm{D}$, better accounting/financial performance and a smaller size. The innovation degree has a lower importance compared to what was found in the first step of analysis. Institutional investors who have no interest in acquiring know-how (acquiring a substantial target patents package) orient their holdings in companies able to guarantee important capital gains on the acquired shareholding because strong investments in R\&D and good performance presuppose growth orientation.

Table 4. Target firms' characteristics in M\&A deals (aim 1 - regression coefficients)

\begin{tabular}{|c|c|c|c|c|c|c|c|c|c|c|c|c|c|c|c|}
\hline \multirow[b]{2}{*}{ Variable } & \multicolumn{15}{|c|}{ Regressions } \\
\hline & 1 & 2 & 3 & 4 & 5 & 6 & 7 & 8 & 9 & 10 & 11 & 12 & 13 & 14 & 15 \\
\hline PAT & $\begin{array}{c}11.54 \\
1\end{array}$ & & & & & & & $19.130^{* *}$ & $19.453^{* *}$ & $19.329^{* *}$ & $8.769^{* * *}$ & $20.582^{* *}$ & $20.178^{* *}$ & $19.376^{* * *}$ & $19.734^{* * *}$ \\
\hline $\mathrm{RD}$ & & -10.768 & & & & & & $-28.245^{* * *}$ & $-30.381^{* * *}$ & $-29.732^{* * *}$ & $-31.719^{* * *}$ & $-35.589^{* * *}$ & $-36.745^{* * *}$ & $-31.476^{* * * *}$ & $29.765^{* * * *}$ \\
\hline ROA & & & -0.113 & & & & & & -0.062 & & & & & 4.665 & $4.267^{* * * *}$ \\
\hline $\mathrm{CF}$ & & & & -0.487 & & & & & & -0.423 & & & & -1.722 & $-2.067^{* * * *}$ \\
\hline LE & & & & & 0.665 & & & & & & 0.117 & & & 0.745 & 0.518 \\
\hline $\mathrm{TA}$ & & & & & & -0.023 & & & & & & -0.067 & & -0.120 & \\
\hline SAL & & & & & & & -0.014 & & & & & & -0.085 & -0.340 & \\
\hline $\mathrm{R}^{2}$ & 0.006 & 0.002 & 0.001 & 0.002 & 0.004 & 0.002 & 0.001 & 0.023 & 0.011 & 0.014 & 0.015 & 0.014 & 0.013 & 0.037 & 0.410 \\
\hline
\end{tabular}

Table 5. Characteristics of target firms acquired from institutional investor (aim 2 - regression coefficients)

\begin{tabular}{|c|c|c|c|c|c|c|c|c|c|c|c|c|c|c|c|}
\hline \multirow[b]{2}{*}{ Variable } & \multicolumn{15}{|c|}{ Regressions } \\
\hline & 1 & 2 & 3 & 4 & 5 & 6 & 7 & 8 & 9 & 10 & 11 & 12 & 13 & 14 & 15 \\
\hline PAT & 19.643 & & & & & & & 19.334 & 29.652 & 22.883 & 30.661 & 24.892 & 22.477 & 23.226 & 26.343 \\
\hline $\mathrm{RD}$ & & $28.174^{* *}$ & & & & & & $26.688^{* *}$ & $38.678^{* *}$ & $29.299 * *$ & $38.042^{*}$ & $24.768 * *$ & $22.554^{* *}$ & $26.511^{* *}$ & $97.833 * *$ \\
\hline ROA & & & $1.047^{* * *}$ & & & & & & $1.665^{* *}$ & & & & & 1.079 & 2.623 \\
\hline $\mathrm{CF}$ & & & & $2.043 * * *$ & & & & & & $2.786^{* * *}$ & & & & 0.355 & 0.623 \\
\hline $\mathrm{LE}$ & & & & & -0.256 & & & & & & -0.533 & & & 0.289 & 0.185 \\
\hline TA & & & & & & $-0.188^{* *}$ & & & & & & $-0.179 * * * *$ & & -0.002 & \\
\hline SAL & & & & & & & $-0.185^{* *}$ & & & & & & $-0.143^{* * * *}$ & -0.161 & \\
\hline $\mathrm{R}^{2}$ & 0.020 & 0.053 & 0.030 & 0.034 & 0.029 & 0.037 & 0.035 & 0.088 & 0.173 & 0.191 & 0.093 & 0.122 & 0.148 & 0.186 & 0.159 \\
\hline
\end{tabular}

Aim 3-describing the effects of M\&A deals on targets. 
Table 6. Descriptive variables: pre-deal average value respect post-deal average value (aim 3)

\begin{tabular}{ccccc}
\hline Variable & Year & Average & $\begin{array}{c}\text { Variation } \\
\text { Absolute value*** }\end{array}$ & Percentage \\
\hline Patent investments* & -1 & 720.55 & -317.04 & $-44 \%$ \\
R\&D investments* & 1 & 403.51 & & \\
ROA & -1 & 102.14 & +62.30 & \\
& 1 & 164.44 & 0 & 0 \\
Cash Flow* & -1 & 0.0321 & & $21 \%$ \\
Leverage & 1 & 0.0345 & 576.62 & $-5 \%$ \\
Sales* & -1 & 2745.85 & -0.03 & $-22 \%$ \\
& 1 & 3322.47 & & \\
Total Asset* & -1 & 0.7833 & -18839.25 & $-26 \%$ \\
\hline
\end{tabular}

Note. * Thousands of euros; ** All the differences are statistically significant at $10 \%$

Observing the indicators of the level of innovation of the targets, it is possible to note, on the one hand, the average value of patent investments after the operation is almost halved $(-44 \%)$, on the other, the one related to R\&D investments shows a solid increase $(+61 \%)$. This effect could be a confirmation of a predominance in the sample of acquirers willing to access a technological advantage (the representative factor is identified in the patent component) and then use the target as an instrument that is useful for promoting the innovation process by attributing to it the task of developing further research and development activities.

The effects of the conclusion of the deal on the target firm's performance can be identified by looking at the differences in the averages in the two considered years with respect to the ROA and Cash Flow (CF) parameters: the profitability of the core business remains unchanged, not suggesting an improvement in the operating efficiency of the company and the company liquidity undergoes, in line with expectations, an average increase of $21 \%$.

The financial structure of the target firms is almost unchanged; finally, looking at the dimensional parameters, a reduction can be seen, both in the value of the average relative to the sales and in the value of the total assets.

\section{Conclusion}

Using a sample of M\&As between 2009 and 2017, some synergy can be identified between the company's innovation activity and participation in operations.

First, we can see that companies with large patent portfolios and low research and development costs are more likely to be targeted. These results are not replicated in the absence of technological overlap; in this case, only the intensity in $R \& D$ is relevant and the performance and size variables become more important.

Considering post-deal effects with respect to the pre-deal period, the most significant effects in terms of entity are on patent and R\&D expenditure, those results confirm that with M\&A transactions synergies are achieved that affect innovation capacity and can be an important incentive to be a part of them.

The analysis carried out in this article does not fill the gap between European and international empirical literatures, but it represents a solid starting point for new future research development.

First of all, the analysis will have to be replicated by inserting other variables related to innovation; in this way, it can overcome the problem of incomplete accounting in the financial statements of some intangible expenses that would be underestimated, for example, instead of patent spending, we could use the number of patents and licenses presented/registered. The innovation variables should also be enriched with variables that can accurately estimate the existence of technology overlap between target and acquirer, so as to understand its weight as a driver, but also the weight that the existence of synergies has on the post-merger period in terms of improving innovation performance and creating value.

International literature highlights that many merger transactions are driven by efficiency, and future research can focus on studying how and if synergy in sectors other than reference can improve it.

\section{References}

Ahuja, G., \& Katila, R. (2001). Technological Acquisitions and the Innovation Performance of Acquiring Firms: 
A Longitudinal Study. Strategic Management Journal, 22, 197-220. https://doi.org/10.1002/smj.157

Andrade, G., Mitchell, M., \& Stafford E. (2001). New Evidence and Perspectives on Mergers. Journal of Economic Perspectives, 15, 103-120. https://doi.org/10.1257/jep.15.2.103

Barney, J. B. (1988). Returns to Bidding Firms in Mergers and Acquisitions: Reconsidering the Relatedness Hypothesis. Strategic Management Journal, 9, 71-78. https://doi.org/10.1002/smj.4250090708

Bena, J., \& Li, K. (2014). Corporate Innovation and Mergers Acquisitions. Journal of Finance, 69, 1923-1960. https://doi.org/10.1111/jofi.12059

Blonigen, B. A., \& Taylor, C. T. (2000). R\&D Intensity and Acquisitions in High-Technology Industries: Evidence from the US Electronic and Electrical Equipment Industries. The Journal of Industrial Economics, 48, 47-70. https://doi.org/10.1111/1467-6451.00112

Bloom, N., Schankerman, M., \& Van Reenen, J. (2013). Identifying Technology Spillovers and Product Market Rivalry. Econometrica, 81, 1347-1393. https://doi.org/10.3982/ECTA9466

Bower, J. L. (2001). Not All M\&As Are Alike—and That Matters, Harvard Business Review, 79, 92-101.

Cantwell, J., \& Santangelo, G. D. (2006). Evolution of Markets, Technology and M\&A. In Cassiman, B., and Colombo, M. G. (eds.), Mergers \& Acquisitions: The Innovation Impact (pp. 28-36). Cheltenham, UK and Northampton, MA: Edward Elgar.

Capron L., Dussauge, P., \& Mitchell, W. (1998). Resource Redeployment Following Horizontal Acquisitions in Europe and North America, 1988-1992. Strategic Management Journal, 19, 631-661. https://doi.org/10.1002/(SICI)1097-0266(199807)19:7\%3C631::AID-SMJ963\%3E3.0.CO;2-9

Cassiman, B., \& Colombo, M. G. (2006). Introduction. In Cassiman, B., \& Colombo, M. G. (eds.), Mergers \& Acquisitions: The Innovation Impact (pp. 64-76). Cheltenham, UK and Northampton, MA: Edward Elgar.

Cassiman, B., \& Reinhilde, V. (2006). In Search of Complementarity in Innovation Strategy: Internal R\&D and External Knowledge Acquisition. Management Science, 52, 68-82. https://doi.org/10.1287/mnsc.1050.0470

Cassiman, B., \& Ueda, M. (2006). M\&A and Innovation: A Conceptual Framework. In Cassiman, B., \& Colombo, M. G. (eds.), Mergers \& Acquisitions: The Innovation Impact (pp. 63-76). Cheltenham, UK and Northampton, MA: Edward Elgar. https://doi.org/10.4337/9781847201584

Cassiman, B., \& Veugelers R. (2006). In Search of Complementarity in Innovation Strategy: Internal R\&D and External Knowledge Acquisition. Management Science, 52, 68-82. https://doi.org/10.1287/mnsc.1050.0470

Chakrabarti, A., Hauschildt, J., \& Süverkrüp, C. (1994). Does it Pay to Acquire Technological Firms?. R\&D Management, 24, 47-56. https://doi.org/10.1111/j.1467-9310.1994.tb00846.x

Cohen, W. M., \& Levinthal, D. A. (1989). Innovation and Learning: The Two Faces of R\&D. The Economic Journal, 99, 569-596. https://doi.org/10.2307/2233763

Comanor, W. S., \& Scherer, F. M. (2012). Mergers and Innovation in the Pharmaceutical Industry. Journal of Health Economics, 32, 106-113. https://doi.org/10.1016/j.jhealeco.2012.09.006

Danzon, P. M., Epstein, A., \& Nicholson, S. (2007). Mergers and Acquisitions in the Pharmaceutical and Biotech Industries. Managerial and Decision Economics, 28, 307-328. https://doi.org/10.1002/mde.1343

Desyllas, P., \& Hughes, A. (2010). Do High Technology Acquirers Become More Innovative?. Research Policy, 39, 1105-1121. https://doi.org/10.1016/j.respol.2010.05.005

Dezi, L., Battisti, E., Ferraris, A., \& Papa, A. (2018). The link between mergers and acquisitions and innovation. Management Research Review, 41, 716-752. https://doi.org/10.1108/MRR-07-2017-0213

Dierickx, I., \& Cool, K. (1989). Asset Stock Accumulation and Sustainability of Competitive Advantage. Management Science, 35, 1504-1511. https://doi.org/10.1287/mnsc.35.12.1504

Fan, J. P. H., \& Goyal, V. K. (2006). On the Patterns and Wealth Effects of Vertical Mergers. The Journal of Business, 79, 877-902. https://doi.org/10.1086/499141

Frey, R., \& Hussinger, K. (2006). The Role of Technology in M\&As: A Firm-Level Comparison of Cross-Border and Domestic Deals. Discussion Paper 1, Economic Studies, Deutsche Bundesbank. https://www.bundesbank.de/resource/blob/618296/b55582c3fa27f773af892b53971cd865/mL/2006-12-30-d kp-45-data.pdf

Gans, J. S., \& Stern, S. (2000). Incumbency and R\&D Incentives: Licensing the Gale of Creative Destruction. 
Journal of Economics \& Management Strategy, 9, 485-511. https://doi.org/10.1111/j.1430-9134.2000.00485.x

Gantumur, T., \& Stephan, A. (2010). Do External Technology Acquisitions Matter for Innovative Efficiency and Productivity? Discussion Paper 1035, DIW Berlin, German Institute for Economic Research, Berlin. https://doi.org/10.2139/ssrn.1652704

Granstrand, O., Bohlin, E., Oskarsson, C., \& Sjöberg, N. (1992). External Technology Acquisition in Large Multi-Technology Corporations. $R \& D$ Management, 22: 111-134.

https://doi.org/10.1111/j.1467-9310.1992.tb00801.x

Grimpe, C., \& Hussinger, K. (2008). Pre-Empting Technology Competition Through Firm Acquisitions. Economics Letters, 100, 189-191. https://doi.org/10.1016/j.econlet.2008.01.003

Grimpe, C., \& Hussinger, K. (2013). Resource Complementarity and Value Capture in Firm Acquisitions: The Role of Intellectual Property Rights. Strategic Management Journal, 35, 1762-1780. https://doi.org/10.1002/smj.2181

Hart, O., \& Holmstrom, B. (2010). A Theory of Firm Scope. Quarterly Journal of Economics, 125, 483-513. https://doi.org/10.1162/qjec.2010.125.2.483

Haspeslagh, P. C., \& Jemison, D. B. (1991). Managing Acquisitions: Creating Value Through Corporate Renewal. New York, NY: Free Press.

Haucap, J., \& Stiebale, J. (2016). How Mergers Affect Innovation: Theory and Evidence From the Pharmaceutical Industry. Discussion Paper 218, Düsseldorf Institute for Competition Economics (DICE), University of Düsseldorf. http://hdl.handle.net/10419/130193

Henderson, R., \& Cockburn, I. (1996). Scale, Scope, and Spillovers: The Determinants of Research Productivity in Drug Discovery. Rand Journal of Economics, 27, 32-59. https://doi.org/10.2307/2555791

Higgins, M. J., \& Rodriguez, D. (2006). The Outsourcing of R\&D Through Acquisitions in the Pharmaceutical Industry. Journal of Financial Economics, 80, 351-383. https://doi.org/10.1016/j.jfineco.2005.04.004

Hoberg, G., \& Phillips, G. (2010). Product Market Synergies and Competition in Mergers and Acquisitions: A Text-Based Analysis. The Review of Financial Studies, 23, 3773-3811. https://doi.org/10.1093/rfs/hhq053

Holmstrom, B., \& Roberts, J. (1998). The Boundaries of the Firm Revisited. Journal of Economic Perspectives, 12, 73-94. https://doi.org/10.1257/jep.12.4.73

Hussinger, K. (2010). On the Importance of Technological Relatedness: SMEs Versus Large Acquisition Targets. Technovation, 30, 57-64. https://doi.org/10.1016/j.technovation.2009.07.006

Jensen, M. C., \& Ruback, R. S. (1983). The Market for Corporate Control: The Scientific Evidence. Journal of Financial Economics, 11, 5-50. https://doi.org/10.1016/0304-405X(83)90004-1

Kaplan, S. N. (2000). Mergers and Productivity. Chicago, IL: University of Chicago Press. https://doi.org/10.7208/chicago/9780226424330.001.0001

Karim, S., \& Mitchell, W. (2000). Path-Dependent and Path-Breaking Change: Reconfiguring Business Resources Following Acquisitions in the US Medical Sector, 1978-1995. Strategic Management Journal, 21, 1061-1081. https://doi.org/10.1002/1097-0266(200010/11)21:10/11<1061::AID-SMJ116>3.0.CO;2-G

Keil, T., Maula, M., Schildt, H., \& Zahra, S. A. (2008). The Effect of Governance Modes and Relatedness of External Business Development Activities on Innovative Performance. Strategic Management Journal, 29, 895-907. https://doi.org/10.1002/smj.672

Lerner, J., Tirole, J., \& Strojwas, M. (2003). Cooperative Marketing Agreements between Competitors: Evidence from Patent Pools. Working Paper 9680, National Bureau of Economic Research, Cambridge MA. https://doi.org/10.3386/w9680

Levitt, B., \& March, J. G. (1988). Organizational Learning. Annual Review of Sociology, 14, 19-38. https://doi.org/10.1146/annurev.so.14.080188.001535

Makri, M., Hitt, M. A., \& Lane, P. J. (2010). Complementary Technologies, Knowledge Relatedness, and Invention Outcomes in High Technology Mergers and Acquisitions. Strategic Management Journal, 31, 602-628. https://doi.org/10.1002/smj.829

Maksimovic, V., Phillips, G., \& Prabhala, N. R. (2011). Post-Merger Restructuring and the Boundaries of the Firm. Journal of Financial Economics, 102, 317-343. https://doi.org/10.1016/j.jfineco.2011.05.013 
Mayer, D., \& Kenney, M. (2004). Economic Action Does Not Take Place in a Vacuum: Understanding Cisco's Acquisition and Development Strategy. Industry and Innovation, 11, 299-325. https://doi.org/10.1080/1366271042000289333

Mowery, D. C., Oxley, J. E., \& Silverman, B. S. (1996). Strategic Alliances and Interfirm Knowledge Transfer. Strategic Management Journal, 17, 77-91. https://doi.org/10.1002/smj.4250171108

Munos, B. (2009). Lessons from 60 Years of Pharmaceutical Innovation. Nature Reviews Drug Discovery, 8 , 959-968. https://doi.org/0.1038/nrd2961

Nooteboom, B., Van Haverbeke, W., Duysters, G., Gilsing, V., \& Van den Oord, A. (2007). Optimal Cognitive Distance and Absorptive Capacity. Research Policy, 36, 1016-1034. https://doi.org/10.1016/j.respol.2007.04.003

Ranft, A. L., \& Lord, M. D. (2000). Acquiring New Knowledge: The Role of Retaining Human Capital in Acquisitions of High-Tech Firms. The Journal of High Technology Management Research, 11, 295-319. https://doi.org/10.1016/S1047-8310(00)00034-1

Ranft, A. L., \& Lord, M. D. (2002). Acquiring New Technologies and Capabilities: A Grounded Model of Acquisition Implementation. Organization Science, 13, 420-441. https://doi.org/10.1287/orsc.13.4.420.2952

Sapienza, H. J., Parhankangas, A., \& Autio, E. (2004). Knowledge Relatedness and Post-Spin-Off Growth. Journal of Business Venturing, 19, 809-829. https://doi.org/10.1016/j.jbusvent.2003.06.002

Schweizer, L. (2005). Organizational Integration of Acquired Biotechnology Companies into Pharmaceutical Companies: The Need for a Hybrid Approach. Academy of Management Journal, 48, 1051-1074. https://doi.org/10.5465/amj.2005.19573109

Seth, A. (1990). Sources of Value Creation in Acquisitions: An Empirical Investigation. Strategic Management Journal, 11, 431-446. https://doi.org/10.1002/smj.4250110603

Teece, D., \& Pisano, G. (1994). The Dynamic Capabilities of Firms: An Introduction. Industrial and Corporate Change, 3, 537-556. https://doi.org/10.1093/icc/3.3.537-a

Vermeulen, F., \& Barkema, H. (2001). Learning Through Acquisitions. Academy of Management Journal, 44, 457-476. https://doi.org/10.1080/00208825.1995.11656654

\section{Copyrights}

Copyright for this article is retained by the author(s), with first publication rights granted to the journal.

This is an open-access article distributed under the terms and conditions of the Creative Commons Attribution license (http://creativecommons.org/licenses/by/4.0/). 